\title{
PENERAPAN MODEL PEMBELAJARAN KOOPERATIF FORMULATE SHARE LISTEN CREATE UNTUK MENINGKATKAN PRESTASI BELAJAR PESERTA DIDIK PADA POKOK BAHASAN KESETIMBANGAN ION DAN PH LARUTAN PENYANGGA
}

\section{Karina Dilla Mustika *, Elva Yasmi Amran, Betty Holiwarni}

Program Studi Pendidikan Kimia, Fakultas Keguruan dan Ilmu Pendidikan Universitas Riau, Kampus Binawidya KM 12,5, Pekanbaru 28293, Riau, Indonesia

\begin{tabular}{l}
\multicolumn{1}{c}{ Informasi Artikel } \\
\hline Sejarah Artikel: \\
Diterima: 11-07-2019 \\
Disetujui : 14-01-2021 \\
Dipublikasikan: 27-01-2021 \\
\hline Keywords: \\
Cooperative Learning, \\
FSLC model, \\
learning achievement, \\
Equilibrium Ion and $\mathrm{pH}$ \\
Buffer Solution \\
\hline
\end{tabular}

\begin{abstract}
A b s t r a k
Penelitian bertujuan untuk meningkatkan prestasi belajar peserta didik pada pokok bahasan kesetimbangan ion dan $\mathrm{pH}$ larutan penyangga di kelas XI MIA SMAN 1 Pekanbaru. Jenis penelitian ini adalah penelitian eksperimen dengan desain pretest-posttest. Penelitian dilaksanakan di SMAN 1 Pekanbaru. Sampel dari penelitian adalah peserta didik kelas XI MIA 6 sebagai kelas eksperimen dan peserta didik pada kelas XI MIA 5 sebagai kelas kontrol. Kelas eksperimen adalah kelas yang diterapkan model pembelajaran kooperatif FSLC. Teknik analisis data digunakan adalah uji-t. Berdasarkan hasil uji analisis data diperoleh $t_{\text {hitung }}>t_{\text {tabel }}$ yaitu 1,78> 1,67, artinya penerapan model pembelajaran kooperatif FSLC dapat meningkatkan prestasi belajar peserta didik pada pokok bahasan kesetimbangan ion dan $\mathrm{pH}$ larutan penyangga di kelas XI MIA SMA Negeri 1 Pekanbaru.
\end{abstract}

\begin{abstract}
The research is aimed to improve student learning achievement on the subject of equilibrium ion and pH buffer solution in class XI MIA SMAN 1 Pekanbaru. This type of research is an experimental study with a pretest-posttest design. The research was conducted at SMAN 1 Pekanbaru. The sample study was included class XI MIA 6 as an experimental class and class XI MIA 5 as a control class. The experimental class was applied the cooperative learning model FSLC. The data analysis technique used is the t-test. Based on the results of the data analysis test, $t_{\text {count }}>t_{\text {table }}$ is $1.78>1.67$, meaning that the application of cooperative learning model FSLC can improve student learning achievement on the subject of equilibrium ion and $\mathrm{pH}$ buffer solution in class XI MIA of SMA Negeri 1 Pekanbaru.
\end{abstract}

(C) 2021 JPK UNRI. All rights reserved

\footnotetext{
*Alamat korespondensi:

e-mail: karinadillamustika10@gmail.com

No. Telf: -
} 


\section{PENDAHULUAN}

Proses belajar mengajar mencakup proses interaksi antar peserta didik, antar peserta didik dengan pendidik dan antar peserta didik dengan sumber belajar lainnya pada suatu lingkungan belajar yang berlangsung secara edukatif agar peserta didik dapat membangun sikap, pengetahuan dan keterampilannya untuk mencapai tujuan yang telah ditetapkan (Kemendikbud, 2016). Keberhasilan proses pembelajaran dapat dilihat dari pencapaian tujuan pembelajaran. Keberhasilan pencapaian tujuan pembelajaran tidak terlepas dari peran guru sebagai fasilitator, motivator dan pembimbing peserta didik dalam meningkatkan kemampuan peserta didik untuk memahami materi pembelajaran yang mengharuskan guru memiliki strategi, metode, media dan model yang tepat agar proses pembelajaran dapat berlangsung efektif, sehingga prestasi belajar peserta didik dapat meningkat.

Untuk mengatasi berbagai problematika dalam pelaksanaan pembelajaran, diperlukan model pembelajaran yang dipandang mampu mengatasi kesulitan guru melaksanakan tugas mengajar dan juga kesulitan belajar peserta didik. Model pembelajaran dapat didefinisikan suatu perencanaan atau suatu pola yang digunakan sebagai pedoman dalam melaksanakan pembelajaran di kelas (Martinis, 2013). Pemilihan model pembelajaran disesuaikan dengan materi pelajaran agar peserta didik tertarik dan termotivasi terhadap materi pelajaran sehingga berdampak pada peningkatan prestasi belajar peserta didik, termasuk dalam pembelajaran kimia.

Informasi yang diperoleh dari hasil wawancara guru kimia kelas XI MIA SMAN 1 Pekanbaru bahwa nilai rata-rata hasil ulangan harian yang diperoleh peserta didik pada materi kesetimbangan ion dan pH larutan penyangga pada tahun 2017/2018 masih tergolong rendah. Hal ini terlihat dari persentase ketuntasan peserta didik hanya sebesar $43 \%$ saja dan $57 \%$ lainnya masih belum mencapai Kriteria Ketuntasan Minimal (KKM) yang telah ditetapkan sekolah yaitu 75. Tidak tercapainya target KKM ini disebabkan kurangnya keterlibatan peserta didik dalam proses pembelajaran. Sebagian peserta didik lebih banyak menunggu sajian materi dari guru tanpa berusaha sendiri untuk menemukan konsep dari pembelajaran yang akan dipelajari. Guru telah berupaya menerapkan metode diskusi kelompok, namun pada penerapannya hanya 1-2 orang peserta didik saja yang terlibat dalam diskusi. Proses pembelajaran didominasi oleh peserta didik yang berkemampuan tinggi, sehingga peserta didik dengan kemampuan menengah kebawah tidak berperan banyak dalam diskusi dimana hanya menunggu jawaban dari temannya. Saat mempresentasikan hasil diskusi, hanya peserta didik yang unggul dalam kelompok saja yang mau mempresentasikan hasil diskusi dan menjawab pertanyaan. Kurangnya keterlibatan peserta didik secara aktif terhadap pembelajaran membuat peserta didik menjadi tidak termotivasi dalam mengikuti proses belajar, sehingga konsep pembelajaran tidak tertanam kuat dalam ingatan peserta didik dan mengakibatkan rendahnya prestasi belajar. Berdasarkan pernyataan tersebut terlihat diperlukannya model pembelajaran yang dapat mendorong peserta didik untuk aktif dan lebih membangun pengetahuannya sendiri yang akan berdampak pada peningkatan prestasi belajar dengan menerapkan model pembelajaran kooperatif Formulate Share Listen Create (FSLC).

Model pembelajaran kooperatif FSLC adalah proses pembelajaran dimana peserta didik secara aktif mengkontruksi pengetahuannya sendiri dengan menyelesaikan permasalahanpermasalahan yang diberikan (Komariya et al., 2018). Menurut Williams (2002) langkah-langkah model pembelajaran FSLC yaitu sebelum bekerja bersama teman sekelompoknya, terlebih dulu peserta didik harus bekerja sendiri dalam merumuskan (Formulate) dan membuat hipotesa dari permasalahan yang diberikan oleh guru, kemudian peserta didik duduk dalam kelompoknya dan secara bergantian berbagi (Share) hasil pemikirannya dengan teman sekelompoknya dan peserta didik lainnya mendengarkan (Listen) dengan seksama apa yang disampaikan oleh teman sekelompoknya. Lalu secara bersama-sama mereka dapat membuat (Create) jawaban yang lebih baik dibandingkan jawaban individu sebelumnya dan bersiap-siap untuk mempresentasikan 
jawabannya di depan kelas. Model pembelajaran kooperatif FSLC menuntut peserta didik untuk mengasah kemampuan awal mereka secara mandiri lalu melakukan diskusi secara aktif dengan teman kelompoknya yang dibimbing oleh guru dan dituntut untuk terlibat aktif dalam proses pembelajaran sehingga peserta didik akan lebih mudah memahami materi pelajaran (Ledlow, 2001). Kelebihan model pembelajaran kooperatif FSLC menurut Johnson et al., (1991) yaitu dapat meningkatkan kemampuan berpikir peseta didik tanpa harus bergantung pada guru, membentuk kemampuan peserta didik dalam menyelesaikan suatu masalah secara sistematik menggunakan strategi yang tepat dan melatih peserta didik dalam mengkomunikasikan ide-idenya baik secara lisan maupun tulisan sehingga berdampak pada peningkatan prestasi belajar. Melalui model pembelajaran kooperatif FSLC, peserta didik akan dilatih untuk dapat memahami permasalahan sehingga ketika dihadapkan pada sebuah permasalahan, mereka sudah terbiasa dan dapat menyelesaikannya (Komariya et al., 2018).

Beberapa penelitian secara konfrehensif mengembangan kan pembalarajan berbasis FSLC. Pilihan, et al., (2013) telah melakukan penelitian mengenai model pembelajaran kooperatif FSLC di kelas XI IPA SMA Negeri 9 Palembang pada mata pelajaran kimia materi termokimia yang menunjukkan peningkatan prestasi belajar pada kelas eksperimen menggunakan model pembelajaran kooperatif FSLC pada siklus 1 peningkatan sebesar 61,88, pada siklus II mengalami peningkatan menjadi 76,25 dan pada siklus III meningkat menjadi 79,13 dengan ketuntasan belajar siswa sebesar 86\%. Afriningsih (2016) telah menerapkan model pembelajaran kooperatif FSLC untuk meningkat pemahaman konsep matematis siswa kelas VIII MTsN Gurun Panjang Kabupaten Pesisir Selatan. Hasil penelitian ini diperoleh bahwa nilai $t_{\text {hitung }}>t_{\text {tabel }}$, dimana nilai $t_{\text {hitung }}=2,36$ dan $\mathrm{t}_{\text {tabel }}=1,68$ ini bermakna kemampuan pemahaman konsep matematis menggunakan model kooperatif FSLC lebih baik dibanding kemampuan pemahaman konsep matematis tanpa model kooperatif FSLC. Penelitian yang lain juga melaporkan model pembelajaran kooperatif FSCL untuk meningkatkan pemahaman konsep matematik siswa (Ruswana, 2019), untuk meningkat kemapuan berkomunikasi matematika siswa (Oktavianti et al. 2020) dan untuk meningkatkan penalaran matematika siswa (Juariah dan Sari, 2014). Penelitian ini bertujuan untuk mengimplementasikan model pembelajaran formulate share listen create untuk meningkatkan prestasi belajar peserta didik. Penelitian ini diterapkan pada pokok bahasan kesetimbangan ion dan $\mathrm{pH}$ larutan penyangga.

\section{METODE PENELITIAN}

Penelitian ini dilaksanakan di SMAN 1 Pekanbaru pada semester genap tahun ajaran 2018/2019. Waktu pengambilan data dilakukan pada bulan Maret-April 2019. Populasi dalam penelitian yaitu kelas XI MIA SMA Negeri 1 Pekanbaru yang terdiri dari 6 kelas yaitu XI MIA 1, XI MIA 2, XI MIA 3, XI MIA 4, XI MIA 5 dan XI MIA 6. Sampel penelitian ini yaitu dua kelas dari anggota populasi yang telah terdistribusi normal berdasarkan uji Liliefors dan homogen berdasarkan uji kesamaan varians dan uji kesamaan rata-rata. Kelas kontrol yaitu XI MIA 5 dengan jumlah peserta didik 35 orang yang diberi perlakuan tanpa penerapan model pembelajaran kooperatif FSLC. Kelas eksperimen yaitu XI MIA 6 dengan jumlah peserta didik 27 orang yang diberi perlakuan penerapan model pembelajaran kooperatif FSLC. Bentuk penelitian adalah penelitian eksperimen dilakukan terhadap dua kelas dengan Desain Randomized Control Group Pretest-Posttest seperti Tabel 1. Teknik pengumpulan data dalam penelitian adalah teknik test prestasi belajar. Data yang dikumpulkan diperoleh dari: (1). Data hasil nilai test soal ulangan kesetimbangan ion dan $\mathrm{pH}$ larutan garam sebagai data awal yang digunakan untuk uji homogenitas. (2). Nilai pretest dan posttest pada kelas eksperimen dan kelas kontrol (pokok bahasan kesetimbangan ion dan $\mathrm{pH}$ larutan penyangga) yang digunakan untuk uji hipotesis. 
Tabel 1. Rancangan Penelitian

\begin{tabular}{cccc}
\hline Kelas & Pretest & Perlakuan & Posttest \\
\hline Eksperimen & $\mathrm{T}_{0}$ & $\mathrm{X}$ & $\mathrm{T}_{1}$ \\
Kontrol & $\mathrm{T}_{0}$ & - & $\mathrm{T}_{1}$ \\
\hline
\end{tabular}

Data dianalisis dengan menggunakan pengujian statistik uji-t untuk melihat peningkatan prestasi belajar peserta didik. Syarat agar dapat dilanjutkan uji-t yaitu dengan kriteria data harus berdistribusi normal. Oleh karenanya, sebelum dilakukan pengolahan data, terlebih dahulu dilakukan uji normalitas dan uji homogenitas. Uji normalitas data menggunakan uji Liliefors, bila harga $\mathrm{L}_{\text {maks }}<\mathrm{L}_{\text {tabel }}$ Harga $\mathrm{L}_{\text {tabel }}$ untuk taraf nyata $\alpha=0,05$, maka data berdistribusi normal (Irianto, 2003).

Pengujian hipotesis yang digunakan yaitu peningkatan prestasi belajar peserta didik pada pokok bahasan kesetimbangan ion dan $\mathrm{pH}$ larutan penyangga setelah diterapkan model pembelajaran kooperatif FSLC. Hipotesis nol (Ho) dan Hipotesis alternatif (Ha) dalam penelitian berbunyi :

$\mathrm{H}_{\mathrm{o}}$ : Peningkatan prestasi belajar peserta didik menggunakan model pembelajaran kooperatif FSLC lebih kecil daripada kelas yang tanpa menggunakan model pembelajaran kooperatif FSLC.

$\mathrm{H}_{\mathrm{a}}$ : Peningkatan prestasi belajar peserta didik menggunakan model pembelajaran kooperatif FSLC lebih besar daripada kelas yang tanpa menggunakan model pembelajaran kooperatif FSLC. Kriteria pengujian $\mathrm{H}_{\mathrm{a}}$ diterima jika $\mathrm{t}_{\text {hitung }}>\mathrm{t}_{\text {tabel }}$ dengan kriteria probabilitas 1- $\alpha$ $(\alpha=0,05)$ dan $\mathrm{dk}=\mathrm{n}_{1}+\mathrm{n}_{2}-2$.

\section{HASIL}

Analisis yang dilakukan terhadap data nilai ulangan pokok bahasan kesetimbangan ion dan pH larutan garam menghasilkan kesimpulan bahwa kelas XI MIA 5 dan XI MIA 6 memiliki data yang normal berdasarkan hasil normalitas dengan uji Liliefors dan juga dapat dinyatakan memiliki kemampuan yang sama setelah diuji varians dan diuji kesamaan rata-rata. Pada awal penelitian kedua kelas diberikan Pretest dan diakhir penelitian kedua kelas diberikan Posttest. Hasil uji normalitas data pretest dan posttest ditunjukan pada Tabel 2.

Tabel 2. Hasil Uji Normalitas data pretest dan posttest

\begin{tabular}{rrcccccc}
\hline Data & Kelas & $\mathbf{N}$ & $\overline{\mathrm{X}}$ & $\mathbf{S}$ & $\mathbf{L}_{\text {maks }}$ & $\mathbf{L}_{\text {tabel }}$ & Keterangan \\
\hline Pretest & XI MIA 5 & 35 & 31,89 & 8,2 & 0,12 & 0,15 & Berdistribusi \\
& XI MIA 6 & 27 & 27,85 & 7,06 & 0,15 & 0,17 & Normal \\
Posttest & XI MIA 5 & 35 & 80,46 & 8,39 & 0,1 & 0,15 & Berdistribusi \\
& XI MIA 6 & 27 & 82,22 & 7,39 & 0,14 & 0,17 & Normal \\
\hline
\end{tabular}

Tabel 2 menunjukkan hasil uji normalitas pretest dan posttest untuk kelas eksperimen dan kelas kontrol. Data pretest dan posttest kelas eksperimen dan kelas kontrol berdistribusi normal karena diperoleh $\mathrm{L}_{\text {maks }} \leq \mathrm{L}_{\text {tabel }}$ yang sesuai dengan ketentuan uji normalitas Liliefors bahwa untuk data yang terdistribusi normal diperoleh $\mathrm{L}_{\text {maks }} \leq \mathrm{L}_{\text {tabel }}$.

\subsection{Uji Hipotesis Penelitian}

Data yang digunakan untuk uji hipotesis dalam penelitian adalah selisih antara nilai pretest dan posttest yang menunjukkan besarnya peningkatan prestasi peserta didik sebelum dan sesudah 
mempelajari materi kesetimbangan ion dan $\mathrm{pH}$ larutan penyangga dengan dan tanpa menggunakan model pembelajaran kooperatif FSLC. Hasil pengolahan data uji hipotesis dapat dilihat pada Tabel 3.

Tabel 3. Hasil Uji Hipotesis terhadap kelas eksperimen dan kontrol

\begin{tabular}{ccccccccc}
\hline Kelas & $\mathbf{N}$ & $\sum \mathbf{X}$ & $\mathrm{X}$ & $\sum \mathbf{X}^{\mathbf{2}}$ & $\mathbf{S}_{\text {gab }}$ & $\mathbf{t}_{\text {hitung }}$ & $\mathbf{t}_{\text {tabel }}$ & keterangan \\
\hline Eksperimen & 27 & 1468 & 54.37 & 80848 & 8.99 & \multirow{2}{*}{1.78} & \multirow{2}{*}{1.67} & $\begin{array}{c}\text { Hipotesis } \\
\text { diterima }\end{array}$ \\
\hline Kontrol & 5 & 1700 & 48.57 & 86384 & & & & \\
\hline
\end{tabular}

Uji hipotesis yang didapat dari selisih nilai pretest-postest dilakukan dengan menggunakan uji t pihak kanan, hasil uji hipotesis $\mathrm{t}_{\text {hitung }}=1.78$ dan nilai $\mathrm{t}_{\text {tabel }}$ pada $\alpha=0.05$ dengan $\mathrm{dk}=60$ adalah 1.67 artinya $t_{\text {hitung }}$ lebih besar daripada $t_{\text {tabel }}$ yaitu $1.78>1.67$ sehingga hipotesis diterima bahwa peningkatan prestasi belajar peserta didik dengan penerapan model pembelajaran kooperatif FSLC dapat diterima.

\section{PEMBAHASAN}

Prestasi belajar peserta didik kelas eksperimen lebih besar dibandingkan kelas kontrol dikarenakan pada kelas eksperimen diterapkan model pembelajaran kooperatif FSLC. Pada penerapan model ini, peserta didik membangun pengetahuannya sendiri dan menemukan konsepkonsep pelajaran yang baru sehingga pengetahuan yang diperolehnya lebih bermakna dan dapat bertahan dalam jangka waktu yang panjang Hasil penelitian ini sesuai dengan penelitian Rika Afriningsih (2016) yaitu pengaruh penerapan model pembelajaran kooperatif FSLC terhadap pemahaman konsep matematis siswa kelas VIII MTsN Gurun Panjang Kabupaten Pesisir Selatan dimana $t_{\text {hitung }}>t_{\text {tabel }}$ dengan nilai $t_{\text {hitung }}=2,36$ dan $t_{\text {tabel }}=1,68$ sehingga kemampuan pemahaman konsep matematis menggunakan model kooperatif FSLC lebih baik dibanding kemampuan pemahaman konsep matematis tanpa model kooperatif FSLC.

Model pembelajaran kooperatif FSLC juga menuntut peserta didik memecahkan masalah seperti peristiwa atau pernyataan pada pokok bahasan kesetimbangan ion dan $\mathrm{pH}$ larutan penyangga dan mampu mengemukakan ide-ide untuk menyelesaikan suatu masalah yang diberikan. Hal ini sesuai dengan pendapat Sanjaya, (2009) bahwa pengetahuan yang dibangun sendiri oleh peserta didik akan menjadi pengetahuan yang bermakna, sedangkan pengetahuan yang hanya diperoleh melalui proses pemberitahuan tidak akan menjadi pengetahuan bermakna. Selain itu, menurut pendapat Bruner yang dikutip oleh Trianto, (2015) bahwa berusaha sendiri untuk mencari pemecahan masalah serta pengetahuan yang menyertainya menghasilkan pengetahuan yang benarbenar bermakna.

Model pembelajaran kooperatif FSLC meliputi empat tahap pembelajaran yaitu formulate, share, listen dan create. Pada tahap formulate, peserta didik dihadapkan pada permasalahan untuk membangkitkan rasa ingin tahu terhadap materi kesetimbangan ion dan $\mathrm{pH}$ larutan penyangga. Permasalahan tersebut disajikan oleh guru dalam bentuk wacana, lalu peserta didik diarahkan untuk merumuskan sebuah jawaban terhadap masalah yang diajukan oleh guru secara individu di dalam lembar formulation yang telah diberikan. Menurut Zaini, (2009) jika peserta didik terlibat aktif dalam pembelajaran, maka kesan penerimaan pelajaran akan melekat lebih lama. Misalnya pada pertemuan pertama peserta didik diberi wacana di lembar formulation mengenai penyangga dalam tubuh manusia, dimana ketika kita memakan berbagai jenis makanan dengan berbagai rasa seperti asam, asin, manis dan lain-lain, $\mathrm{pH}$ darah kita tetap stabil dengan kisaran 7,3-7,4. Sehingga dari wacana tersebut muncul suatu permasalahan yang harus diselesaikan oleh peserta didik secara individu. Tahapan formulate ini merupakan tahapan penting disebabkan peserta didik akan dilatih 
untuk dapat memahami permasalahan sehingga ketika dihadapkan pada sebuah permasalahan, mereka sudah terbiasa dan dapat menyelesaikannya sendiri (Sulistiana, 2017).

Tahap selanjutnya yaitu Share dan Listen dimana peserta didik duduk dalam kelompoknya lalu peserta didik saling berbagi dan mendengarkan jawaban teman sekelompoknya dengan menganalisis persamaan dan perbedaan jawaban antar anggota kelompok dengan menuliskannya di lembar share dan listen. Selama proses pembelajaran, peserta didik terlihat lebih aktif di dalam kelompoknya ketika saling berbagi jawaban dan mendengarkan pendapat teman sekelompoknya. Hal ini sesuai dengan pendapat Arikunto (2002) bahwa adakalanya seorang peserta didik lebih mudah menerima keterangan yang diberikan oleh teman sebangku atau teman yang lain karena tidak ada rasa enggan atau malu untuk bertanya dan meningkatkan kepercayaan dirinya.

Tahap terakhir yaitu create dimana peserta didik berdiskusi untuk memberikan jawaban atas pertanyaan atau masalah dengan menggabungkan ide-ide terbaik dari diskusi. Proses diskusi seperti ini dapat membuat peserta didik lebih aktif dalam menanggapi atau bertanya jika tidak mengerti dengan konsep yang sedang dipelajari, melatih rasa tanggung jawab dan toleransi dalam menghargai pendapat sesama teman kelompok. Menurut Ledlow (2001) bahwa peserta didik dapat meningkatkan kemampuannya dalam berinteraksi dengan teman sekelompoknya dengan cara bertukar pikiran saat menyelesaikan soal dan berbagi ide dengan teman sekelompoknya.

\section{DAFTAR PUSTAKA}

Afriningsih, R. Melisa, Hamdunah. 2016. Pengaruh Penerapan Model Pembelajaran Kooperatif Tipe FSLC terhadap Pemahaman Konsep Matematis Siswa Kelas VII MTsN Gurun Panjang Kabupaten Pesisir Selatan. Jurnal FKIP Matematika. 2(1): x-xx

Arikunto, S. 2013. Dasar-dasar Evaluasi Pendidikan. Bumi Aksara. Jakarta

Irianto, A. 2003. Statistika Konsep Dasar dan Aplikasi. Jakarta. Kencana.

Johnson, D. W., Johnson, R. T., \& Smith, K. A. 1991. Cooperative learning: increasing college faculty instructional productivity. Washington, DC: ASHE/ERIC Higher Education.

Juariah, Sari, R. 2014. Penerapan Model Pembelajaran Kooperatif Dengan Formulate Share Listen Create (FSLC) Untuk Meningkatkan Kemampuan Penalaran Matematis Siswa. Jurnal Kreano. 5(2): 143-149

Kemendikbud. 2016. Bahan pelatihan Kurikulum 2013 tahun 2016. Jakarta : Kemendikbud.

Komariya, N. Farida, Vahlia, I. 2018. Pengaruh Model Pembelajaran FSLC Terhadap Kemampuan Pemecahan Masalah Matematika Ditinjau dari Motivasi Belajar Siswa. Aksioma Jurnal Pendidikan Matematika. 7(1); 96-102

Ledlow, S., 2001. Using Think-Pair-Share in the College Classroom. Arizona: Arizona State University. www.hydroville.org/system/files/team_thinkpairshare.pdf (Akses tanggal 18 September 2019)

N.W. Oktavianti, I.W.P. Astawa, Sariyasa. 2020. Pengaruh Model Pembelajaran Kooperatif Tipe Formulate Share Listen Create (FSLC) Terhadap Kemampuan Komunikasi Matematis Siswa Kelas X SMA Negeri 1 Payangan. Wahana Matematika dan Sains: Jurnal Matematika, Sains, dan Pembelajarannya. 14(1):148-155

Pilihan, A.K., Anom, Edi. R. 2013. Peningkatan Hasil Belajar Siswa Dalam Pembelajaran Kimia Melalui Penerapan Model Formulate, Share, Listen and Create (FSLC) di Kelas XI IPA 3 SMA Negeri 9 Palembang. Jurnal Pendidikan Kimia FKIP Universitas Sriwijaya. 1(1); x-xx

Ruswana, A.M. 2019. Meningkatkan Kemampuan Pemahaman Matematis Mahasiswa melalui Pembelajaran Kooperatif Tipe Formulate-Share-Listen-Create (FSLC). Prisma Sains: Jurnal Pengkajian Ilmu dan Pembelajaran Matematika dan IPA IKIP Mataram. 7(1):91-99

Sanjaya, W. 2009. Strategi Pembelajaran Berorientasi Standar Proses Pendidikan. Kencana Prenada Media Group. Jakarta

Sulistiana, I. Kartika, T. Fikri. 2017. Kemampuan Penalaran dan Komunikatif Matematis dengan Penerapan Model Pembelajaran FSLC (Formulate-Share-Listen-Create) pada Materi Aritmatika Sosial JP3. Jurnal Universitas Islam Malang 7(20); x-Xx

Trianto. 2010. Model Pembelajaran Terpadu. PT. Bumi Aksara. Jakarta 
Trianto. 2015. Mendesain Model Pembelajaran Inovatif, Progresif, dan Kontekstual; Konsep, Landasan, Implementasi pada Kurikulum 2013. Prenadamedia Group. Jakarta

Williams, R., 2002. Cooperative Learning A Standard for High Achievement. America : Corwin

Zaini, H. 2008. Strategi Pembelajaran Aktif. Institut Agama Islam Negeri Sunan Kalijaga. Yogyakarta. 